\title{
Methodological approaches to the study of mineral resource potential of regions
}

\author{
Myroslav Syvyj ${ }^{1}$, Ordenbek Mazbayev², Olena Volik ${ }^{3}$, Natalia Panteleeva ${ }^{4, *}$, and Olena Hanchuk ${ }^{4}$ \\ ${ }^{1}$ Ternopil Volodymyr Hnatiuk National Pedagogical University, 2, Maxyma Kryvonosa str., Ternopil, 46027, Ukraine \\ ${ }^{2}$ L. N. Gumilyov Eurasian National University, 2 Satpayev Str., Nur-Sultan, 010008, Republic of Kazakhstan \\ ${ }^{3}$ University of Waterloo, Department of Geography and Environmental Management, Ontario, Canada \\ ${ }^{4}$ Kryvyi Rih State Pedagogical University, 54, Gagarina Ave., Kryvyi Rih, 50086, Ukraine
}

\begin{abstract}
The exploration industry of Ukraine is experiencing a protracted crisis. It is confirmed by the curtailment of funding for the development of country mineral resources by $60 \%$ last year which causes the closure of exploration companies. The range of problems traditionally solved by the geography of mineral resources is significantly reduced. These reasons encouraged us to consider the main methodological approaches to the study of mineral potential of specific regions. The studied approaches such as naturalgeographical, economic-geographical, ecological-geographical, and complex structural-geographical lie in the domain of geographical science. The article emphasizes the urgency to develop structural and geographical course of research, which is based on the studies of mineral resources and the approaches mentioned above including geological one. The structural and geographical course of research is supposed to create real models of mineral resources of the country regions and to suggest specific measures of their structure optimization alongside prospects of their development following modern world tendencies. The research may result in the creation of a long-term concept of balanced development of the mineral complex of the region, the prevision of the use of mineral resources, the justification of resource-saving technologies. A systematic approach to such a concept will ensure the rational use of resources, the formation of new infrastructure, conditions for environmentally safe function of the economy, sustainable and balanced development of the economic complex of the region.
\end{abstract}

\section{Introduction}

The geography of mineral resources as a sphere of study does not currently develop in Ukraine. There are almost no publications with the results of natural and geographical studies on the regularities of formation and territorial localization of deposits of different types of minerals, and analysis of their impact on the formation of mining complexes. The problems of effective functioning of regional mineral complexes and optimization of their structure are scientifically neglected. We believe that it is obvious and long overdue the need for a comprehensive (constructive-geographical) approach to the study of mineral resources (MR) of definite regions and the country as a whole. The efficient use of mineral resources based on modern technologies with combination of the economic efficiency of exploration and processing of mineral resources with minimum negative environmental impact can lead to optimal solutions of present complex economic and social problems. In this context the authors suggest a brief overview of methodological approaches to the study of mineral resources and their opinions on the constructive and geographical direction of their study.
To provide a comprehensive systematic approach to constructive-geographical studies of mineral resources of specific regions, it is essential to include the following basic interrelated areas of research: geologicalmineralogical, natural-geographical (geo-morphological, paleo-geo-morphological, paleo-geographic, landscape, etc.), economic-geographical and geographical ones.

The geological and mineralogical course of MR research is the most extensive and elaborated approach, and involves a comprehensive study of mineral resources from the material composition study to the development of general concepts of prospecting and exploration of minerals in continental areas, oceans, certain administrative units. The analysis of the development of geological and mineralogical research of the MR universally and in Ukraine is the subject of special consideration which goes beyond the scope of this publication.

The natural and geographical studies made by Ukrainian researchers explore: paleo-geographic and paleo-landscape conditions of mineral formation and forecasts of their deposits by M. Veklych [1, 2].

E. Palienko [4], M. Volkov, V. Palienko, I. Sokolovsky [5], V. Palienko [3] study paleo-geomorphological, geo-morphological, morpho-structural 
and neo-tectonic criteria for prospecting and exploration of mineral deposits. Landscape-geochemical approaches to the study of mining areas were substantiated by E. Ivanov [7, 8, 18] and others.

The economic and geographical direction of the $M R$ study in Ukraine is represented by the works of I. Gorlenko [10, 11], V. Mishchenko [26], M. Palamarchuk, I. Gorlenko, T. Yasnyuk [12]; M. Palamarchuk, O. Palamarchuk [13]; L. Rudenko, V. Palienko, L. Shevchenko [14, 15, 16] and others.

Ecological and geographical research. We notice that a relatively small number of thorough researches are devoted to the issues of subsoil protection during exploration and mining works. The significant number of publications studies the problems of the negative environmental impact of mining generally or discretely. These are the works of G. Rudko, L. Shkitsa [20], G. Rudko, E. Ivanov, I. Kovalchuk [8] and others. These works consider environmental problems of mining in the context of general environmental issues, propose methodological approaches to their solution, and analyze reasons of ecological crisis situations in certain regions.

The historical course of MR research is represented by works exploring the issues of formation and development of mineral sciences, history of discovery and study of mineral resource potential of definite territories, history of mining in the context of general civilization process, etc. (M. Syvyj [19] and others).

Constructive-geographical approach to the study of mineral resources and related issues are actively promoted in the works of: L. Rudenko, V. Palienko, L. Shevchenko and others[14], L. Rudenko, V. Palienko, V. Baitala and others [15], L. Rudenko, V. Palienko, M. Barshchevsky and others [16], M. Syvyj [17], M. Syvyj, I. Paranko, Ye. Ivanov [18], and others.

Research methods. Research was based on such general principles of cognition as objectivity, causality, universal connection, evolutionary. From the traditional general scientific methods, the following were used: observation (field method), analysis and synthesis, induction and deduction, comparison and analogy, generalization and abstraction, modeling and forecasting.

Within the framework of a constructive-geographical approach to the study of the mineral resource base of the Podillia region, natural-geographical, economicgeographical and ecological-geographical approaches were used, which made it possible to learn the specifics of the mining and industrial nature management of the region and substantiate the principles of its optimization.

The principles of constructive-geographical research of regional environmental management, developed in the works of I. Horlenko [10, 11, 12], I. Kovalchuk [8], V. Paliienko and L. Rudenko [14, 15, 16], H. Rudko [8, 20, 21] and others.

Constructive-geographical analysis, assessment and forecasting of the development of the region's mineral resources complex were carried out on the basis of the proposed algorithmic research schemes. Such schemes made it possible to optimize the research process, to provide a diversified study of mineral resources on the basis of formalization, automation and unification of analytical and synthesizing studies, bringing them to the level of guidance or instruction.

\section{Results and discussion}

Natural and geographical studies using geological exploration data make it possible to establish and detail the genetic patterns of formation and localization of different types of minerals in the region, predict the location of deposits in new areas and increase reserves within known deposits. They also may determine mining, geological and geo-ecological conditions for future exploitation of deposits, and predict the change in the qualitative characteristics of mineral resources in the area of deposits, etc.

An important form of natural and geographical studies is paleo-geographic reconstructions, which help to reproduce the components of ancient nature of a region: paleo-geology, paleo-relief, paleo-hydrology, paleoclimates, flora and fauna, facile complexes, etc. Paleogeographic, paleo-landscape and lithological-facile maps based on the results of such reconstructions give an idea of the conditions of mineral accumulation in specific areas and can reliably predict the area of its localization.

M. Veklich [1, 2] carries out paleo-geographic and paleo-geo-morphological studies to predict titanium, zirconium, rare earth deposits within the Ukrainian Shield, as well as studies the conditions of formation of manganese ore deposits in the Nikopol Basin and Cenozoic lignite deposits in Ukraine.

Geo-morphological studies solve a number of important problems while search, exploration and development of mineral deposits. At the stage of geomorphological search, two types of geo-morphological objects are studied: resource-containing and resourceinformative [3, 4]. The former include modern or hidden landforms of various origins, which contain deposits of minerals: placers, building materials, peat, coal, oil, gas, etc.; the latter indicative landforms that allow targeted exploration for minerals. At the stage of field exploration, the assessment of the relief of the location area is prioritized to organize the infrastructure of mining enterprises and to prevent the dangerous geomorphological processes that can reveal in productive and adjacent areas. At the stage of mineral deposit development, the main concern is natural resource rational use, protection and preservation of the natural environment.

Morpho-structural and neo-tectonic studies find particularly successful application in the search for structurally conditioned oil fields in the oil and gas provinces of Ukraine $[5,6]$. They are accompanied be the solution of the problems dealing with the determination of optimal structural and geomorphological conditions of hydrocarbon accumulation, neo-tectonic conditions of their migration, etc.

Morpho-structural studies in areas of active tectonic disturbances contribute to the identification of belts and nodes of ore formation of tin, lead, copper, nickel, tungsten, uranium and other ore minerals. 
Complex morpho-metric, morpho-dynamic, historical and geomorphological studies are ultimately useful for search and exploration of deposits of diamonds, titanium, zirconium, gold, particularly within the Ukrainian Shield, and in other territories. Historical-genetic, paleo-geomorphological studies are helpful in searching for brown and hard coal deposits, etc.

Among landscape studies, special attention should be paid to those that involve solving such problems as [7, 8]:

- analysis of the current landscape and geochemical condition in the mining regions of Ukraine;

- substantiation of landscape-geo-chemical approaches to the study of mining areas in order to predict the negative impact of extraction and processing of mineral resources on landscape complexes;

- development of recommendations for the preservation and restoration of the diversity of landscape complexes within the areas of extraction and in the territories nearby to the development sites.

Economic and geographical research is the necessary condition for determination of the areas of MR rational use. Such studies establish regional geographical patterns of mineral deposits [9], the degree of their study and degree of development, the structure of industrial relations between mining enterprises, the structure of sectoral and regional consumption of minerals, market conditions, etc. $[10,11,12,13]$. Economic and geographical studies determine the feasibility and integrated development of mineral deposits, the degree and direction of processing of basic and related minerals, the possibility and effectiveness of mining waste utilization, and so on. They consider possibilities of formation of territorial-production complexes of mineralraw material direction (as one of the most expedient and progressive forms of rational use of mineral resources) on the basis of separate explored deposits or their territorial groups. L. Rudenko, V. Palienko, L. Shevchenko and others [14] highlight extraordinary importance of formation of territorial-production complexes on the basis of minerals for Ukraine. Their research should be a priority in finding ways to improve resource use.

Generally, economic and geographical studies of MR are conducted in three directions: branch, functional and territorial $[10,11,13]$.

Branch direction of the research involves considering the needs of mining industries, their role in structuring industrial complexes. Simultaneously, branch research establishes the level of concentration of certain types of territorial-production complexes, peculiarities of stock placement, mining and hydrogeological conditions, technical and economic indicators of field operation, possibilities and expediency of the complex development, and industrial processing of raw materials.

Branch division aims at the further development of industries based on the development of minerals, establishing their impact on the territorial division of labor and determining the optimal proportions, considering national interests. The results of the study enable to establish the scale of mineral use of a particular region, the potential of expanding and improving the relevant industries within the region.
The functional direction of the study of MR comprises two stages of research [13, 17, 18]. The first stage determines the complex-forming properties of minerals, the developmental prospects of territorial-industrial complexes; and clarifies the nature and degree of the mineral influence on the division of labor in the district.

The second stage of the functional direction of the MR study specificates their role in the functional structure of industry, in the formation of its main links - inter-sector production complexes. At this stage, complexes basing on the use of MR are formed. They are mineral orientated production complexes, such as coal and metallurgy, oil and gas, mining and chemical, etc. The study of mineral orientation systems allows identifying ways of improvement their sector functional structure and territorial organization on the basis of integrated use of minerals, including exploitation and processing of minerals, as well as ways to improve internal and external relations through the use of local resources, reduction of long-distance transportation of raw materials, and transport expanses accordingly.

Territorial direction of MR research involves the study of their impact on the territorial structure of production, especially on the formation of territorial production complexes. To identify the importance of mastering the forms of territorial concentration of mineral deposits in the development of the territorial structure of industry, the researchers distinguish territorial production complexes which are based on mineral resources: centers, nodes, agglomerations, areas of mineral orientation [10, $13,17,18]$. The composition of minerals determines the production orientation of such complexes.

Peculiarities of deposits (structure, capacity of productive horizons, mineral-petrographic composition of minerals) also affect the role of the corresponding industrial complex in the territorial division of labor. The composition of the MR determines the number of specialization areas of such complexes.

The ultimate goal of the territorial MR study is to develop ways to improve the territorial structure of industry on the basis of rational use of mineral resources, which is necessary to ensure optimal territorial organization of production, the implementation of longterm spatial planning.

The geo-ecological (environmental) direction of the MR research developed predominantly due to the necessity to study the processes accompanying the exploration, extraction and primary processing of minerals $[7,8,16,20]$. It was caused by the urgent needs of monitoring, analysis, forecasting and minimization of negative impacts of mining and processing industries on the environment. The development of rational schemes of ecologically safe functioning of mineral complexes in the general context of nature optimization added to its importance. Ecological and geographical research is aimed at studying the impact of mineral resource development on the ecological and geographical situation of the regions, substantiation of the principles of ecological policy of these regions to preserve and improve the environment and create favorable living conditions. The influence of mining complexes on all elements of the regions' environment is studied: disturbances and changes 
in the land fund, air pollution, soil and groundwater, violation of their hydrological regime, etc. The consequence of ecological and geographical studies of the mineral resource base should be the development of a set of measures to improve the quality and preservation of the region natural environment, and the solution of such an urgent environmental problem as justification of reclamation of mining landscapes $[15,16]$. Research and publications on MR environmental issues primarily focus on seven issues: protection and rational use of subsoil, surface and groundwater, air, reclamation of lands destroyed by mining, utilization of mining waste, ecological and landscape problems of destroyed areas, resource security and sustainable development issues.

A comprehensive (constructive-geographical) approach to the study of mineral resources lies in the analysis and synthesis of factual data, theoretical and methodological developments of geological, natural, economic, geo-ecological and historical areas of MR study. It aims at solving a number of problems and issues as following: factual assessment of the state of study of the region mineral resource base, assessment of active and stand-by reserves of mineral resources, establishment of patterns of territorial distribution (territorial structure) of the MR, substantiation of opportunities to increase reserves of explored deposits and assessment of promising areas, diversification of the mineral resource of the region, recommendations on the policy of resource conservation and resource substitution in the region, substantiation of the main ways of using the region MR, determination of the place and role of MR in the economic complex of the region, studying the supplies of the region and its administrative units with certain types of mineral resources and recommendations for covering mineral deficit, selection of resource-saving technologies for extraction and processing of raw materials, development and implementation of programs for reclamation of destroyed lands and utilization of mining waste, optimization of environmental situation in the region, etc. [17].

It is obvious and long overdue the need for a comprehensive systematic approach to the study of mineral resources of particular regions, oblasts and districts. The efficient use of mineral resources by means of modern technologies combining the economic efficiency of exploration and processing of mineral resources with minimum environmental negative impact can be one of the ways leading to optimal solutions of present complex economic and social problems. The program of mineral resource base development of Ukraine for the period up to 2030 [24] provides the solutions for urgent problems of the mineral resource complex, the increase of primarily strategic mineral raw materials reserves to ensure stable operation of industrial and agro-industrial complexes in the future. The program suggests comprehensive (geological, engineeringgeological, ecological-geological, etc.) study of the territory of Ukraine for the purpose of development of state nature protection policy and counteraction to dangerous natural and technogenic disasters and processes.
The constructive geographical researches with the focus on a comprehensive approach to the analysis of the state and development of mineral potential of the regions can pose an especial value.

Presently we consider very significant from a constructive and geographical point of view the design of the optimal correlation of the rate of development of mining enterprises (industries) and the growth (or creation) appropriate mineral resources. It is urgently required a scientifically grounded comprehensive nearterm forecast of the state and regional needs of Ukraine in specific types of mineral resources, based on the actual possibilities of the extraction, the growth of reserves and the geo-ecological situation. The foundation of the economic policy of the state requires the assessment of the mineral potential and the possibilities of its most rational and cost-effective implementation.

On the basis of the above mentioned considerations, Ukraine relevant issues are related to a thorough and comprehensive analysis of mineral resources of some regions and the whole state in order to optimize the functioning of mining and processing industries, creating reliable and effective models of sustainable development, as well as issues of rational use of subsoil resources and solving environmental problems of mining areas.

This is the range of issues that science of constructive geography addresses, one of the key tasks of which is the scientific substantiation of rational use of nature in the regions of Ukraine; and the comprehensive study and consideration of zone, provincial and local natural resources and conditions. The area of interest issues of constructive geography relates to the accumulation, analysis and synthesis of all factual data concerning the study, distribution, development and primary processing of mineral resources and the solution of environmental problems provoked by the above processes. These tasks are under consideration of not only constructive geography, but also geology, mineragraphy, geomorphology, paleo-geography, economic geography, economic geology, hydrogeology, geo-ecology, which intermittently causes inconsistency of the proposed solutions.

Therefore, the essence of constructive-geographical research of mineral resources lies in a comprehensive analysis and evaluation of this type of resources being an important component of integrated natural resource potential of the territory. It also suggests the forecast of development trends and ways to optimize the functioning of mineral complexes, assessment the exploration and mining impact on the geo-ecological situation and substantiation of management decisions on the efficient use of mineral resources, utilization of mining waste and minimization of the negative consequences of mining operations in the regions $[15,17,18]$.

For the solution of such tasks as constructivegeographical analysis, assessment of MR and the prospect of development of region mineral complexes, a number of algorithmic research schemes were compiled and tested [17]. These schemes enable the optimization of the research process; streamline the study of various aspects of MR with the simultaneous improvement of the result quality. They strive to formalize, automate and unify the 
analytical and synthesizing procedures of MR region research, changing them guidance or instruction.

Algorithms make it possible to identify the structure, the mechanisms of functioning of mineral complexes, and the trends in their development, to identify the ways of subsoil resources rational use, and to improve the region ecology. They provide for the solution of both theoretical and practical problems, primarily such as methodological justification of strategic directions of complex development, their role in economic complexes of regions, MR integrated use and utilization of mining waste, reduction of environmental tensions, etc.

An important element of the algorithms is the creation of an information database on the current state of the region MR. Scientific analysis and synthesis of information on mineral resources of the territory (region, economic area) requires a huge amount of statistical, cartographic, departmental, and literary data of the quality, quantity and cost parameters of resources. The creation of a data bank comprising information generalization on the territorial categories of three levels: local, oblast and regional ones is ultimately required.

The local level represents information on MR collected within administrative districts (or territorial communities presently). These are general data on individual deposits, ore occurrences, operating and standby mining and processing enterprises, as well as preliminary information on qualitative and quantitative parameters of mineral resources of each deposit, their mining-geological and hydro-geological characteristics, volume of production and sales, complexity of use of mineral raw materials, waste and environmental protection measures at each specific mining enterprise. The information allows making substantiated conclusions about the mineral potential of individual administrative districts, determination of the optimal directions of socioeconomic development of grassroots territorial units.

The oblast level should provide the collection, accumulation and synthesis of information on MR of separate areas, their potential, ways of optimization use, and considering obtained data substantiates the directions of oblast mineral complexes development in the line with the national concept of mineral base development.

The regional level generalizes the information, combines data on several areas of the region (economic region) and assists the development of mineral resources of large regions of the country, determines the specifics of socio-economic development of large areas.

Thus, the first step in the study of region MR should be made in the creation of a database containing the most diverse and complete information about the object of study. It should be based on a combination of the component and territorial approaches to the formation of a single system of nature management, aimed at solving structural and geographical problems of study, rational use and protection of mineral resources.

Collection of source information in modern conditions is complicated by the fact that statistical authorities receive almost no formalized reports from exploration and mining enterprises and therefore the actual data have to be collected in separate organizations, which to some extent related to the study and exploitation of mineral resources.
The main source of information about mineral resources of Ukraine is the State Research and Production Enterprise State Information Geological Fund of Ukraine "GEOINFORM UKRAINE". It is an institution of the Ministry of Ecology and Natural Resources of Ukraine which collects stores and provides information accumulated in the process of geological study and subsoil use. Geoinform Ukraine has complete, reliable and objective information on the geological study of the territory of Ukraine, the current state and prospects of development of mineral resources and geological environment, the world situation of mineral resources, and legal aspects of subsoil use.

Regional state departments of ecology and natural resources accumulate information on environment protection measures carried out at mining enterprises (air, water environment, land protection and reclamation works, etc.).

The next stage of constructive-geographical study of region MR involves the analysis of the collected factual material. At this stage, the information is grouped by individual types of raw materials, appropriate cartographic models are built (preferably for each type of raw material), which allow to identify patterns of territorial concentration of deposits and manifestations of minerals within the region. The comparison of the constructed models on different types of mineral raw materials allows to allocate territories (areas, macro bushes and bushes) with the maximum accumulation of raw material resources and, on the contrary, the territories poor in mineral resources. Such models can serve as a reliable basis for optimization of the mining infrastructure of the region, the integration of production based on the rational use of mineral resources, etc. [17, 18].

The study of stratigraphic sections of individual deposits allows establishing their belonging to certain stratigraphic horizons, which helps define the prospects of mineral deposits of certain areas of the region.

Coefficients of industrial exploration of districts are determined: ratio of reserves of industrial categories to total explored reserves of mineral raw materials. The analysis of the development degree of the mineral deposits fund is conducted: assignment of deposits to certain categories (the developed deposits, deposits prepared for operation, reserved ones, deposits eliminated from the balance sheet, deposits aggravated because of certain circumstances: fully explored reserves objects, built-up objects, located on the territory of nature protection objects, etc). The coefficients of development of each mineral are determined (the ratio of reserves of developed deposits to the reserves of all explored deposits). The distribution of existing and reserve deposits within the region is studied, and it is analyzed the current level of extraction of certain types of raw materials at specific mining enterprises, administrative districts and regions. The trends in the extraction of certain types of raw materials are identified. The annual coefficients of provision of mining enterprises with explored reserves are calculated: the ratio of reserves of industrial categories to annual production volumes. It is also established the potential of extraction of definite types of mineral raw materials at the mining enterprises on areas, oblast and 
province. The ratios between the volumes of raw materials extracted by local enterprises and imported into the region are calculated. An important task of constructive-geographical study is the analysis of the state, region, districts and areas needs of specific types of mineral resources.

The results of analytical research help establish the actual and potential use of MR in the regional and state economy $[17,18]$ in modern conditions, and consider the ways of effective expanding use of MR.

The next element of constructive-geographical research of $\mathrm{MR}$ of regions is their constructivegeographical estimation.

N. Ratner [25] proposes to assess the mineral resource base from two standpoints: industrial and regional. The economic assessment of region MR applies some differences in its approach. If the purpose of the industrial assessment of the MR is to establish the supply of raw materials needed to meet the objectives of the industry, the regional assessment involves the rational use of mineral resources considering ecological balance, determining the role and place of each resource in economic development.

The assessment of mineral resources is based on a rational combination of regional and industrial principles, taking into account economic costs and effects, as well as a set of industrial and regional assessment factors.

Industrial factors (geological, mining, technical and economic) form the socially necessary costs and the estimated price of raw materials. Regional ones (production integration, infrastructure, environmental situation) determine the effect of territorial organization of production and the efficiency of regional use of production resources (labor, material, financial), necessary to achieve this goal [25].

The ideas presented above lie in the basis of consideration of the constructive-geographical assessment of region MR as a consistent solution to the following issues [18]:

- the determination of the industrial value of deposits and manifestations of minerals;

- the assessment of the MR provision of administrative units of regions;

- the assessment of the territorial-production structure of mineral complexes of the regions and the peculiarities of its functioning;

- the assessment of economic and territorial productivity of MR territories;

- the assessment of the rational use of MR;

- the assessment of the environment impact of mining companies in the regions;

- the management decision taking based on constructive and geographical assessments of region MR.

The assessment can be carried out in stages. Firstly, it is assessed the resources of definite industries, secondly, the resources of the region in general.

The ultimate result of such assessment of mineral deposits and their region manifestations is in making decisions on the feasibility of the operation of existing quarries (mining camps, mines), increasing the volume of extraction or conservation on the contrary; determination the prospects and sequence of the operation of the deposits; recommendations for the assessment of promising minerals and additional exploration of deposits with the depleted reserves.

This comprehensive approach to the study of each deposit forms a holistic view of the real value of the deposit regional fund and, accordingly, addresses the feasibility of their operation in modern market conditions or in the future, establishes the futility of individual deposits.

Construction of maps (models) of territorial density and MR security of administrative units of the region helps reliably estimate the saturation density (saturation coefficient - the ratio of the amount of explored industrial reserves to the area of the administrative unit, ton / acre) by individual types of raw materials and districts. The same approach is applied to the assessment of the supply (ton / person) of specific types of mineral resources of administrative units, as well as certain sectors of the economy of the region.

An important task of the research is to assess the needs of regions (at the present stage and in the near future, taking into account market conditions) in the products of local mining complexes; to determine the estimated supply of raw materials from other regions of Ukraine or abroad; to assess critically the existing use of mineral raw materials for various purposes and to justify the proposals on their efficient and rational use.

The further assessment is made on complexity of the mineral resource use of specific deposits and accumulated mining waste in the region. The following aspects should be taken into account: the total use of the main and related components of the deposits, the selective extraction, transportation and separate storage of extracted components, etc. The mining waste pollution maps of the region territory are built and on their basis such wastes are estimated as potential resources of various industries or agriculture. The scales and ways of region utilization of overburden rock, lateral rock and bedrock, enrichment waste and waste of secondary processing of mineral raw materials are also estimated. As a result of the listed evaluation procedures, a generalized prognostic assessment of the use of region mining waste is given both through the construction of recycling enterprises and the reorientation of the existing relationships between enterprises.

The procedure of economic and geographical assessment of region mineral resources mentioned above includes the typology of the latter; assessment of their component by types of raw materials and territorial structure, as well as the separation of territorial or mining production complexes with mineral orientation; assessment of their structure, relationships and features of functioning. As a result of economic and geographical research, it is substantiated the assessment of the production complexation possibilities on the basis of the optimization model of the structure of the mineral complex, rational approaches to the use of MR and mining waste in the region. The final stage of the MR assessment determines general negative environment impacts of mining production and perspective directions of reclamation measures in the region. 
The ultimate result of constructive-geographical research should be a long-term concept of development of the region mineral complex, a forecast of the use of mineral resources [26], and the resource-saving technology justification. A systematic approach to the creation of such a concept may ensure the rational use of resources and the design of new infrastructure, maintenance of the conditions for environmentally friendly functioning of the economy, and balanced development of the region economic complex. The development of the concept aimed at forecasting the main events and tendencies in the mineral and raw material complex of the region should undoubtedly be carried out on a large scale, comprehensively, in line with the national decisions.

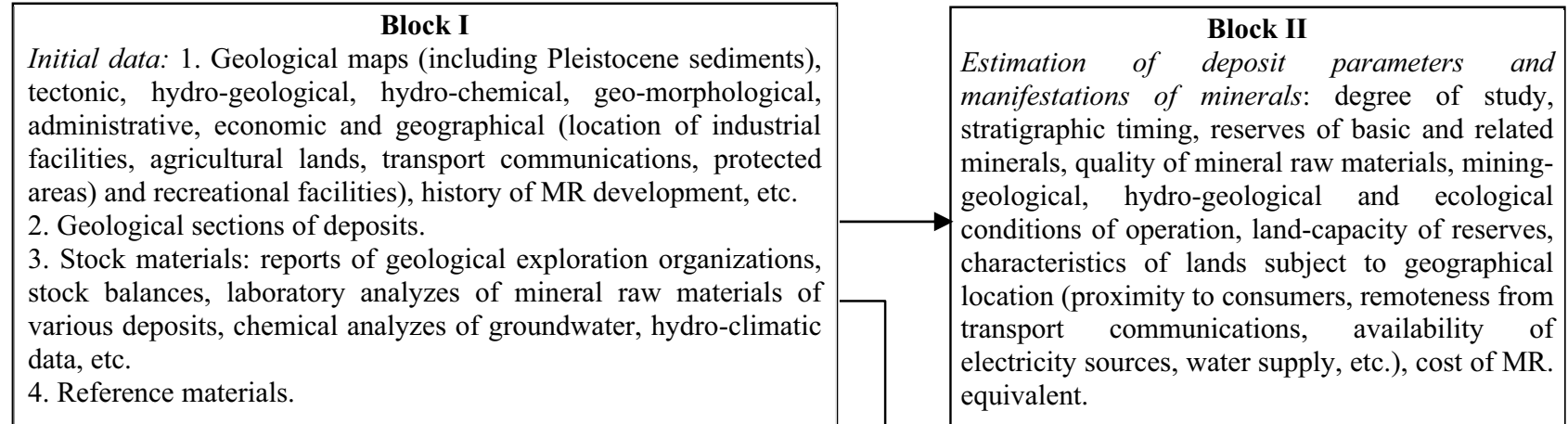

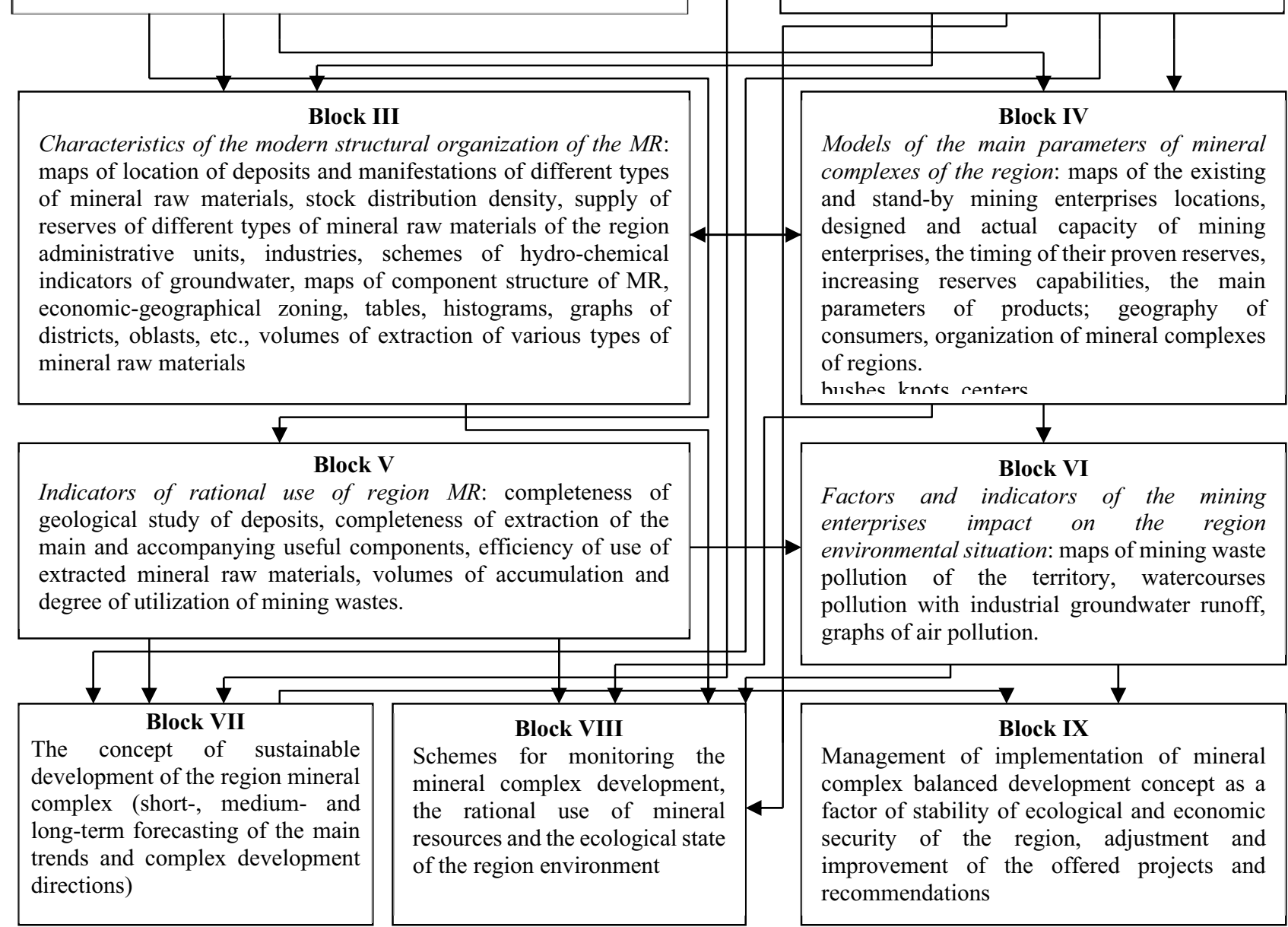

Fig. 1. Block diagram of structural and geographical studies of the regions.

We believe that the concept, concerning national priorities, should take into account the following range of issues:

1. Substantiation of long-term policy of socioeconomic development of the region.

2. Proposals for optimal consumption of raw materials by various sectors of the economy, ways of covering the shortage of certain types of raw materials in future.

3. Substantiation of recommendations for the creation of mineral complexes on the basis of new, unusual for
Ukraine types of raw materials (eg, saponites, apatites, granular phosphorites, glauconites in Podillya, etc.). The thorough preliminary structural and geographical analysis enables to offer a list of such deposits for investment and priority exploitation.

4. Development of scientifically substantiated forecasts of region needs of specific types of raw materials for the short, medium and long terms. The forecast takes into account the actual volumes of raw material extraction in the region, the possibility of increase or import from 
other regions; the expediency of development of the deposits of certain types of raw materials explored in the region, which are currently imported from remote areas.

5. Submission of detailed recommendations on comprehensive, waste-free, rational use of mineral resources of the region.

6. Suggestion of the set of measures aimed at improving the environment in the areas of mining with minimization of its negative impact. Possible changes in the ecological state of the region are forecast considering the increase of production capacity at mining enterprises or the development of new mineral resources for intensively developing industries.

7. Anticipation and implementation of a system of monitoring of environmental protection measures carried out in the region and the consequences of their implementation.

8. Prediction of the socio-economic effect of the mineral resource base expansion, optimization of MR use, improvement of the region ecological condition.

9. Development of recommendations for the optimization of the infrastructure of the region mineral complex.

Generally a block diagram (Fig. 1) demonstrates the sequence and content of constructive-geographical studies of mineral resources of regions.

Constructive-geographical approaches to the study of mineral potential of certain regions of the country are actively introduced into the educational process of a number of higher education institutions of Ukraine (Lviv National University named after I. Franko, Chernivtsi National University named after Yu. Fedkovych, Kryvyi Rih State Pedagogical University, Ternopil National Pedagogical University and V. Hnatyuk). Ternopil National Pedagogical University and V. Hnatyuk delivers in particular a course "Geography of Mineral Resources of Ukraine" for Master degree students, in which methodology structural and geographical research lie in the basis of the presentation of educational materials on the characteristics of the main groups of minerals, the basic laws of their component, functional, territorial structure, their effective use, environmental problems of major mining areas.

\section{Conclusions}

1. Modern research of mineral resource potential of any territory is based on several basic methodological approaches: geological-mineralogical, naturalgeographical, economic-geographical, economic, ecological-geographical, historical and complex constructive-geographical, each of which focuses on separate aspects of studying mineral resources (criteria for prospecting and exploration of minerals, quality composition of raw materials, mining and geological conditions of their extraction, problems of rational efficient use, structure of formed or forecasted economic complexes with clear mineral orientation, subsoil protection, ecological problems of mining areas).

2. We developed the main provisions of the actual constructive-geographical approach to the study of mineral resources of the regions. It consists of the factual data analysis and synthesis, theoretical and methodological findings of the above approaches. The constructive-geographical approach aims to identify spatial (territorial) and temporal-dynamic patterns of mineral resources and their role in the region economic complexes for substantiation of optimization proposals on the structure and efficiency. It also enables the assessment of the environmental stress in the regions caused by mining and processing, search for ways and means to minimize it, general improvement of nature management in the regions.

3 . For the solution of the problems of constructivegeographical study of region mineral resource potential, we created and tested a number of algorithmic schemes in the Podolsk region which went through several successive stages. The first stage was devoted to the formation of the database containing various and the most complete information on the object of study at the local, area and regional levels. The database combines component and territorial approaches to the formation of a single system of nature management in the study area. The second stage of constructive-geographical study of region MR provided analysis of the collected factual material which enabled to create cartographic models of territorial concentration of different types of mineral raw materials, and determine the needs of region, oblasts, separate districts (territorial communities) in specific types of mineral raw materials in their economic complexes. The analysis of the collected factual material provided the consideration on the extra ways of efficient resource use. The third stage involved assessing the mineral resource potential of the territory done in stages. Firstly, the assessment of the resources of separate industries, then the general resources of the region was done. Secondly, the assessment of the complexity of mineral resources of specific deposits and accumulated mining waste in the region, then the typification of mineral resources, assessment of their component and territorial structure. Thirdly, the estimation of possibilities of complexing of manufacture on the basis of optimization model of structure of a mineral resource complex was proved. At the last stage a long-term concept of development of the mineral complex of the region was created, the forecast of use of mineral raw materials and substantiation of use of resource-saving technologies were offered. There were considered the possible changes of region ecological condition caused by production capacity increase at mining enterprises or development of new mineral resources.

4. The methodology of constructive-geographical study of mineral resource potential in recent years is actively introduced into the educational process of geographical departments of higher education institutions in Ukraine.

\section{References}

1. M. Veklych, Paleogeomorphlohia Ukrainskoho shszyta (mezozoi i kajnozoi) (Paleogeomorphology of 
the Ukrainian shield (Mesozoic and Cenozoic)). (Naukova dumka, Kyiv, 1966), p. 120

2. M. Veklych, PhGG, 14, 3-8, (1975)

3. V. Palienko, Neogeodinamika i jeje otraszenie $v$ reljefe Ukrainy (Neogeodynamics and its branches prices in the relief of Ukraine). (Naukova dumka, Kyiv, 1992), p. 116

4. E. Palienko, Poiskovaja $i$ inczhenernaja geomorfologia (Prospecting and engineering geomorphology). (Vyshsza shkola, Kyiv, 1978), p. 198

5. N. Volkov, V. Palienko, I. Sokolovskyj. Morphostrukturnyj analiz neftegazonosnych oblastej Ukrainy (Morphostructural analysis of oil and gas regions of Ukraine). (Naukova dumka, Kyiv, 1981), p. 216

6. V. Palienko, M. Barshchevskyi, R. Spytsia et. all., Morphostrukturno-neotektonicznyj analiz terytorii Ukrainy (konceptualni zasady, metody I realizacia) (Morphostructural-neotectonic analysis of the territory of Ukraine (conceptual framework, methods and implementation). (Naukova dumka, Kyiv, 2013), p. 263

7. Ye. Ivanov, Geokadastrovi doslidszennia hirnyczopromyslovych terytorij (Geocadastre researches of mining territories (Publishing Center of Lviv University, Lviv, 2009), p 371

8. H. Rudko, Ye. Ivanov, I. Kovalchuk, Hirnyczopromyslovi heosystemy Zachidnoho rehionu Ukrainy (Mining geosystems of the Western region of Ukraine), V. 1.2. (Bukrek, Kyiv - Chernivtsi, 2019), p. 838

9. V. Burka, NZChU, Geog. 762-763, 117-126 (2015)

10. I. Horlenko, RPSURSR, 10, 36-44, (1969).

11. I. Horlenko, Konstruktivvno-geografizheskie osnovy prirodopolzovania $v$ Ukrainskoj SSR (Constructive and geographic bases of nature management in the Ukrainian SSR). (Naukova dumka, Kyiv, 1990), p. $89-92$

12. M. Palamarczuk, I. Horlenko, T. Jasnuk, Mineralnyje resursy $i$ formirovanie promyshlennych territorialnych kompleksov (Mineral resources and the formation of industrial territorial complexes). (Naukova dumka, Kyiv, 1978), p. 220

13. M. Palamarchuk, O. Palamarchuk, Ekonomichna ta sotsialna heohrafiia Ukrainy $z$ osnovamy teorii (Economic and social geography of Ukraine with the basics of the theory). (Znannia, Kyiv, 1998), p. 416

14. L. Rudenko, V. Paliienko, L. Shevchenko et. all, UGJ, 4, 11-18 (2003)

15. L. Rudenko, V. Paliienko, V. Bajtala et. al., UGJ, 3, 13-19 (2004)

16. L. Rudenko, V. Paliienko, M. Barshchevskyi et. all., UGJ, 3, 18-23 (2005)

17. M. Syvyj, Mineralni resursy Podillya: konstruktyvnoheohrafichnyy analiz $i$ syntez (Mineral resources of Podillya: constructive-geographical analysis and synthesis), (Pidruchnyky i posibnyky, Ternopil, 2004), p. 654

18. M. Syvyj, I. Paranko, Ye. Ivanov, Heohrafia mineralnych resursiv Ukrainy) (Geography of mineral resources of Ukraine) (Prostir, Lviv, 2013), p. 683

19. M. Syvyj, S. Hulyk, JGGG, 28 (4), p. 757-769 (2019)

20. H. Rudko, L. Shkitsa, Ekolohiszna bezpeka ta razionalne pryrodokorystuvannia $v$ mechach hirnyczopromyslovych I naftohazovych kovpleksiv (Ecological safety and rational nature management within the mining-industrial and oil and gas complexes). (ZAT Nichlava, Ivano-Frankivsk, 2001), p. 525

21. H. Rudko, Ye. Yakovliev, MRU, 3, p. 37- 44 (2020)

22. V. Hrinov, A. Khorolskyi, O. Kaliushchenko, MRU, 2, p. 46-50 (2019)

23. S. Vyzhva, M. Kurylo, A. Balega, MRU, 4, p. 12-17 (2018)

24. Zahal'noderzhavna prohrama rozvytku mineral'nosyrovynnoyi bazy Ukrayiny na period do 2030 roku (National program for the development of mineral resources base of Ukraine for the period until 2030), https://zakon.rada.gov.ua/laws/show/3268-17\#Text. Accessed 17 Jul 2020

25. N. Ratner, Ocenka razvitia mineralno-syrjevogo kompleksa promyshlenno osvoennogo regiona (Assessment of the development of the mineral resource complex of an industrially developed region). (Nauka, Moskva, 1987), p. 95

26. V. Mishchenko, Prohramne planuvannia rozvytku mineralno-syrovynnoi bazy Ukrainy: metodolohija $i$ praktyka (Program planning of the development of the mineral and raw material base of Ukraine: methodology and practice). (DU IEPSR NAN Ukraine, Kyiv, 2011), p. 156 